\title{
Impacts of Coronavirus COVID-19 on the Global Shipping and Maritime Industry in Indonesia and How to Overcome the Coronavirus Outbreak Based on WHO and IMO recommendations
}

\author{
Mohammad Danil Arifin ${ }^{1}$ \\ ${ }^{1}$ Department of Marine Engineering, Faculty of Ocean Technology \\ Darma Persada University, Jakarta \\ E-mail: \\ danilarifin.mohammad@gmail.com \\ mohammad_danil_arifin@ftk.unsada.ac.id
}

\begin{abstract}
Since entering the World Trade Organization (WTO) in 2001, the global share of Chinese container shipments grew up from $10 \%$ in 2003 to $14 \%$ in 2019. While the share of imports of dry bulk commodities to world volumes has jumped sharply from only $11 \%$ to $34 \%$ in the same period. Based on the total dry bulk commodities, the portion of China in the global market is very dominant and become the major player in this industry. China imports $20 \%$ of chemicals, $18 \%$ gas, and $16 \%$ crude oil in 2019. It is understandable that the turmoil in China will have an upstream and downstream impact in the global production chain including Indonesia. The rapid spread of coronavirus has had a major impact on global shipping markets, with the slump in demand for goods from China having a ripple effect on everything from container ships to oil tankers. The freight rate for global container lines generally drops at a sharp rate of $10 \%-15 \%$. A radical drop in demand for Chinese crude tankers from an average of 3.4 billion tonne miles per day in 2019 to almost zero. This was just the start of what was about to become a global crisis for all sectors including shipping. Therefore, this study aims to analyze the impacts of the Coronavirus COVID-19 on the maritime industry especially in Indonesia, and how to overcome the coronavirus outbreak based on World Health Organization (WHO) and International Maritime Organization (IMO) recommendations. The research method used in this research is the study of literature with a descriptive analysis approach.
\end{abstract}

Keyword: Coronavirus COVID-19, Maritime Industry, Global Shipping Industry, Global Crisis, WHO, IMO 


\section{Pendahuluan}

Baltic and International Maritime Council (BIMCO) mengingatkan dampak yang lebih serius dari merebaknya Coronavirus di China terhadap industri pelayaran dan perdagangan jika bencana tersebut terus berlanjut dan tak teratasi dalam waktu dekat. BIMCO menjelaskan, sejak Januari hingga pada 26 Februari, kehilangan volume pelayaran sudah tembus angka 1,7 juta TEUs ${ }^{1}$. Angka tersebut berdasarkan jumlah pembatalan pelayaran mulai tahun baru China (Imlek) serta rendahnya tingkat isian (load factor) sejumlah pelayaran selama merebaknya virus tersebut karena kekurangan volume barang. Penurunan tersebut juga merupakan dampak dari berkurangnya angkutan truk di sisi darat sehingga menyebabkan rendahnya pergerakan kontainer dari dan ke pelabuhan-pelabuhan di China.

BIMCO menjelaskan hampir 2/3 sopir truk di sejumlah wilayah China belum masuk kerja. Analis BIMCO Peter Sand memaparkan tiga kemungkinan yang akan terjadi dengan dampak yang berbeda terhadap kegitan pengiriman. Pertama, jika China berhasil melakukan pengendalian dalam waktu dekat, aktivitas pabrik-pabrik China akan normal pada bulan Maret. Kemungkinan kedua, normalisasi tidak terjadi hingga April; dan ketiga (yang terburuk) virus terus menyebar dengan cara yang tidak mungkin untuk diprediksi atau dianalisis. Jika kemungkinan pertama yang terjadi, maka dampaknya terhadap aktivitas supply chain global relatif kecil. Jika kemungkinan kedua yang terjadi, apalagi kemungkinan ketiga, dampaknya akan lebih serius baik terhadap manufaktur, transportasi, pelayaran, dan kegiatan kepelabuhanan. Saat ini berhentinya aktivitas produksi berdampak pada menurunnya volume kontainer. Namun jika hal ini terus berlanjut, akan menggangu rantai pasok hingga sampai aktivitas retail. Merebaknya virus corona telah membuktikan betapa tingkat ketergantungan industri pelayaran terhadap perekonomian China begitu tinggi. Jika aktivitas industri di China berhenti beroperasi, industri pelayaran akan stuck ${ }^{2}$.

\footnotetext{
${ }^{1}$ BIMCO, 2020

2 Sand (BIMCO), 2020
} 
Sebagai negara pertama yang terkena Covid-19, sekarang China adalah satu-satunya negara dengan ekonomi yang pulih dan populasi yang muncul kembali. Terlihat bahwa, sebaran pandemi COVID-19 semakin hari-semakin meningkat. Sebanyak 212 negara terinfeksi COVID-19, dengan total kasus per 5 Mei 2020 sebanyak 3.646.225 kasus, meninggal sebanyak 252.408 kasus, dan berhasil sembuh sebanyak 1.200.203 kasus seperti terlihat pada Gambar 1. dibawah ini:
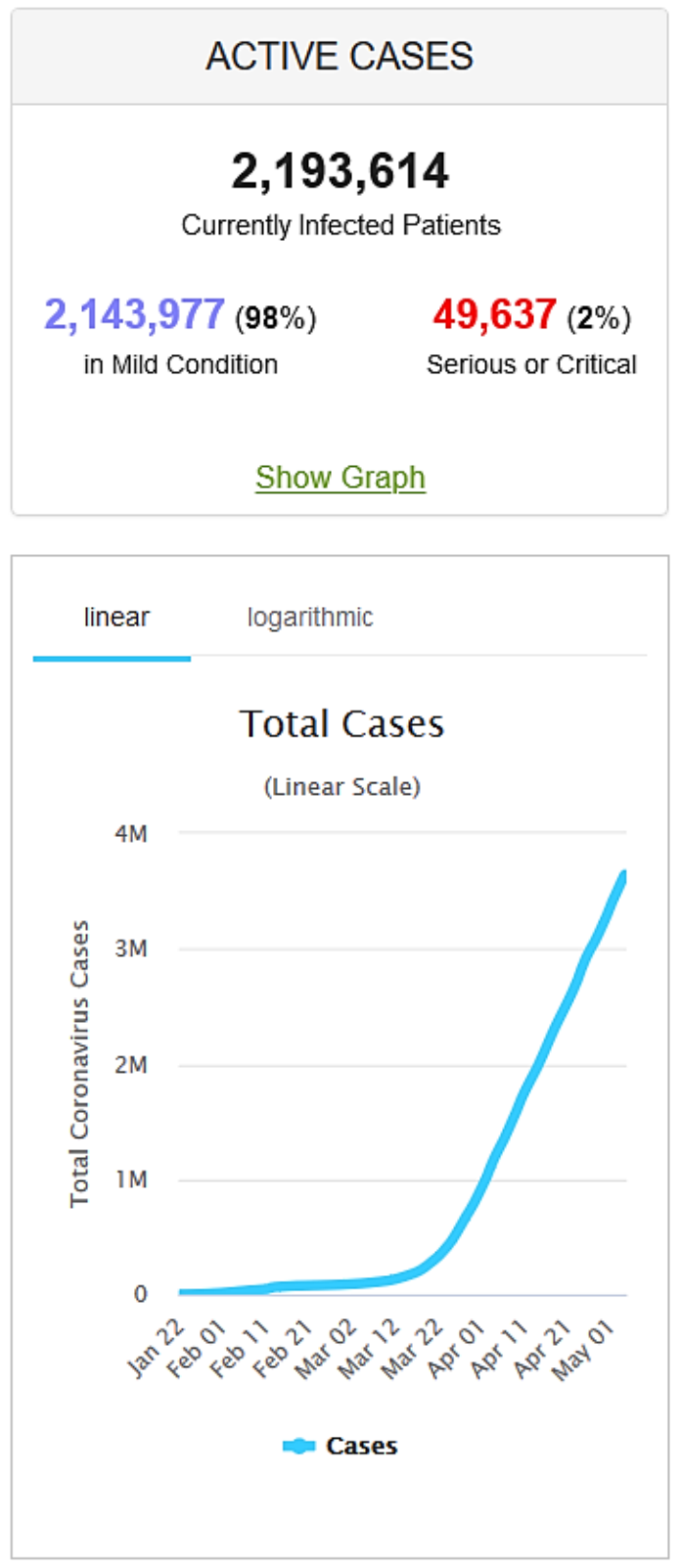
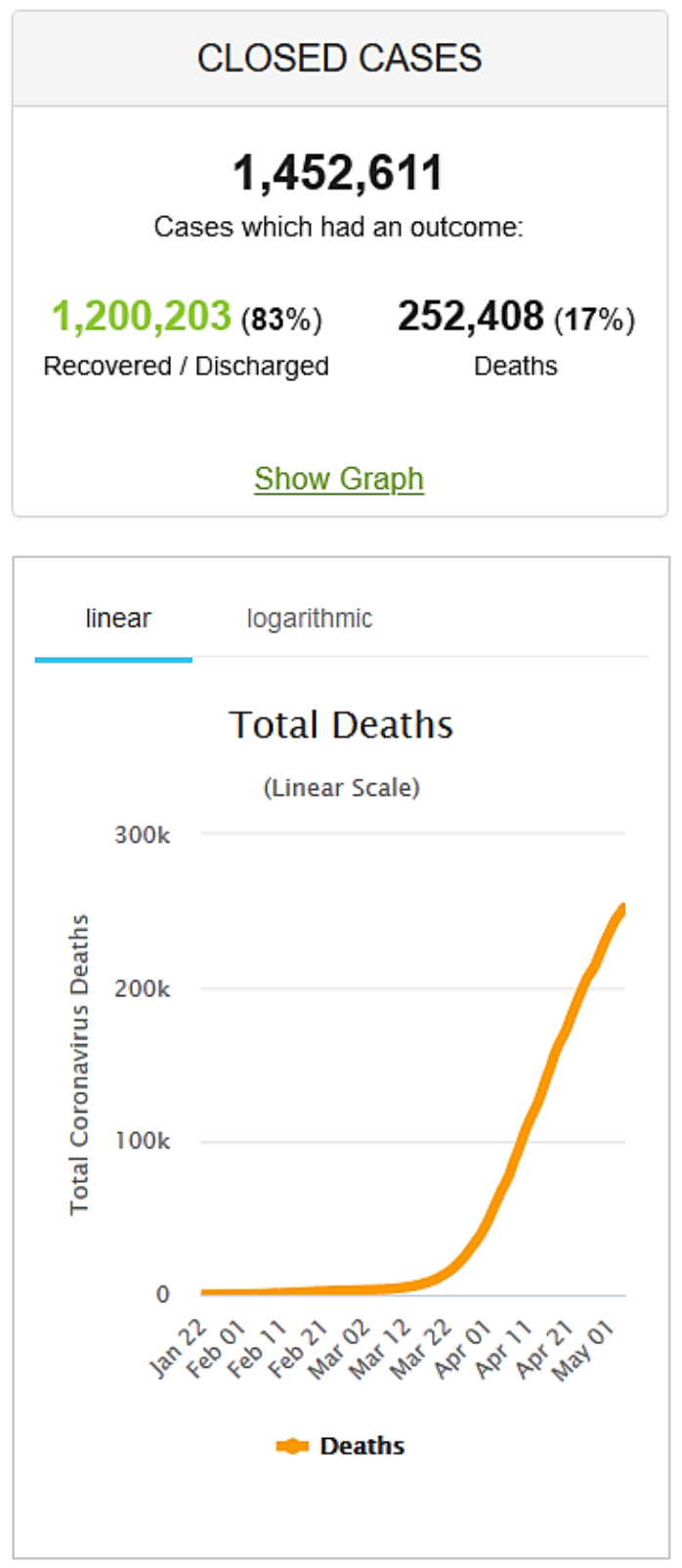

Gambar 1. Data Statistik Infeksi Coronavirus COVID-19³

\footnotetext{
${ }^{3}$ https://www.worldometers.info/coronavirus/, 2020
} 
Dengan adanya hubungan kasualitas antara pandemi COVID-19 yang terjadi di Wuhan, China dengan perekonomian global memicu penulis untuk menganalisa lebih jauh mengenai dampak yang ditimbulkan terhadap kondisi global shipping dan industri kemaritiman khususnya di Indonesia. Serta, menganalisa pola penanganan oleh pemerintah Indonesia terhadap pengawasan dan pencegahan masuknya masuknya Coronavirus COVID-19 ke wilayah Indonesia melalui sektor maritim berdasarkan rekomendasi dari World Health Organization (WHO) dan International Maritime Organization (IMO) dan pihak terkait lainnya.

\section{Metode Penelitian}

Metode yang digunakan dalam penelitian ini adalah studi kepustakaan, yaitu segala usaha yang dilakukan oleh peneliti untuk menghimpun informasi yang relevan dengan topik atau masalah yang akan atau sedang diteliti. Informasi itu dapat diperoleh dari buku-buku ilmiah, laporan penelitian, karangan-karangan ilmiah, tesis dan disertasi, peraturan-peraturan, ketetapan-ketetapan, buku tahunan, ensiklopedia, dan sumber-sumber tertulis baik tercetak maupun elektronik lain ${ }^{4}$. Atau dengan kata lain, studi kepustakaan adalah studi yang objek penelitiannya berupa karya-karya kepustakaan baik berupa jurnal, buku artikel dalam media massa, maupun data-data statistika ${ }^{5}$. Kepustakaan tersebut akan digunakan untuk menjawab permasalahan penelitian yang diajukan oleh penulis yang dalam hal ini adalah bagaimana dampak dari Coronavirus COVID-19 terhadap global shipping dan industri kemaritiman di Indonesia serta usaha pencegahan dan penanganan oleh pemerintah Indonesia berdasarkan rekomendasi WHO dan IMO. Adapun sifat dari studi yang dilakukan adalah deskriptif analisis yaitu merupakan penelitian yang berusaha mendeskripsikan suatu gejala, peristiwa dan kejadian yang terjadi pada saat sekarang dimana peneliti berusaha memotret peristiwa dan kejadian yang menjadi pusat perhatian untuk kemudian digambarkan sebagaimana adanya ${ }^{6}$. Tujuannya adalah untuk memberikan edukasi dan pemahaman kepada pembaca terhadap fenomena yang terjadi.

\footnotetext{
${ }^{4}$ http://repository.usu.ac.id, 2020

${ }^{5}$ Dana Riska Buana, 2020

${ }^{6}$ Nana Sudjana dan Ibrahim (1989: 64)
} 


\section{Diskusi}

\subsection{Dampak Coronavirus COVID-19 Terhadap Global Shipping}

Saat virus korona baru memasuki fase awal, yakni ketika wabah masih melanda Wuhan dan China, dampak terhadap sektor logistik dan ekonomi secara umum sudah sangat terasa. Wuhan berada di jalur sungai Yangtze yang cukup sibuk dengan arus barang. Lebih dari $80 \%$ lalu lintas sungai China bergerak melalui Sungai Yangtze, yakni terdapat volume kargo sekitar 1,5 juta peti kemas dari Wuhan saja. Wilayah di sekitarnya merupakan pemasok komoditas-komoditas penting seperti batu bara, baja, minyak mentah, dan pupuk. Implikasinya adalah, distorsi aktivitas perekonomian di kota ini saja sudah cukup mengganggu rantai pasok yang kemudian berpengaruh kepada perekonomian China. Selanjutnya dengan dominasi China yang sangat kuat dalam perekonomian global, dampaknya pada perekonomian dunia akan dengan sangat cepat terasa.

Sejak masuk menjadi Organisasi Perdagangan Dunia (WTO) pada tahun 2001, pangsa global pengiriman peti kemas China tumbuh dari hanya 10\% pada tahun 2003 menjadi 14\% pada tahun 2019. Sedangkan porsi impor komoditas curah kering terhadap volume dunia melonjak dengan sangat tajam dari hanya $11 \%$ menjadi $34 \%$ pada periode yang sama. Komoditas curah kering adalah bahan baku yang digunakan dalam proses produksi selanjutnya mencakup biji-bijian, logam, dan energi. Dari keseluruhan komoditas curah kering tersebut, porsi China dalam pasar global sangat dominan. China mengimpor $20 \%$ bahan kimia, $18 \%$ gas, dan $16 \%$ minyak mentah pada tahun 2019. Bisa dipahami bahwa gejolak yang terjadi di China akan menimbulkan dampak hulu dan hilir dalam mata rantai produksi global.

\subsubsection{Penurunan Permintaan (Demand) Container}

Sektor transportasi adalah salah satu garda terdepan yang terimbas gejolak perekonomian ini. Penundaan dari berbagai aktivitas logistik dalam dua bulan terakhir telah mengurangi volume kargo peti kemas di pelabuhan regional China, termasuk Hong Kong dengan jumlah lebih dari 6 juta Twenty Equivalent Unit (TEUs). Akibatnya, sampai dengan pekan ketiga Januari, jumlah panggilan kapal (call) di pelabuhan-pelabuhan utama China turun sebesar $20 \%$. 
Kelesuan ini diperkirakan menggerus penerimaan perusahaan pelayaran peti kemas global dengan banyaknya pelayaran kosong (blank sailing) akibat ketiadaan kargo. Dengan asumsi penurunan kargo sebesar US\$1,7 juta dan dengan tarif rata-rata US\$1.000 per TEUS, kerugian perusahaan peti kemas global ditelaah berkisar US\$ 1,7 miliar hingga kuartal pertama tahun 2020. Penurunan permintaan yang terjadi juga dapat dikorelasikan dengan penurunan nilai Purchasing Manager Index (PMI) dan pertumbuhan ekspor dari China seperti pada Gambar 27.

Terlihat bahwa PMI terpuruk pada posisi terbawah pada tahun 2020 setelah sebelumnya juga berada pada posisi terbawah pada tahun 2009. Penurunan PMI yang signifikan ini menjadi indikasi penurunan aktifitas di sektor manufaktur secara menyeluruh yang berdampak pada kondisi perekonomian di China dan mempengaruhi kondisi perekonomian global.

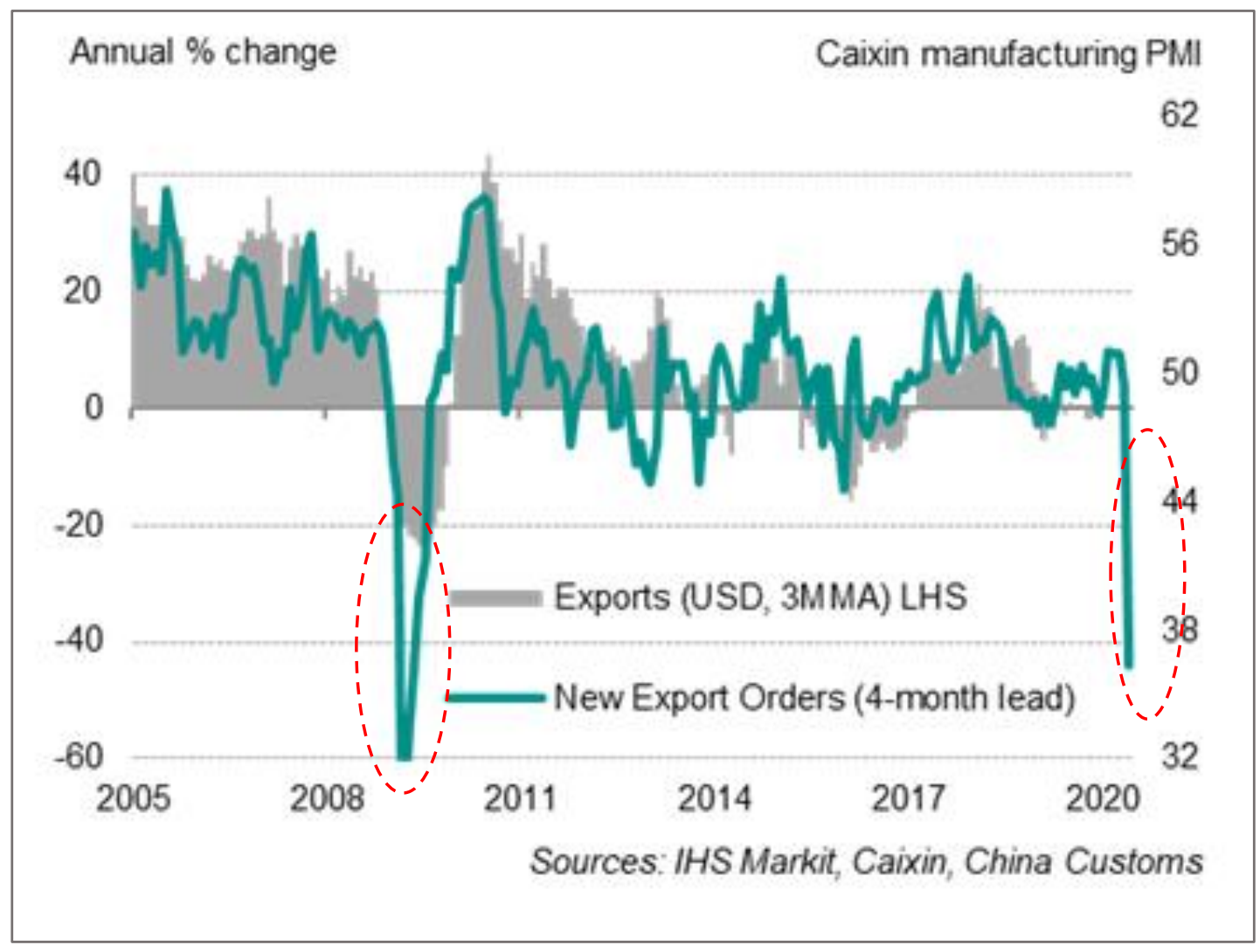

Gambar 2. Caixin China PMI and Export Growth

\footnotetext{
${ }^{7}$ HIS Markit, Caixin, China Customs
} 


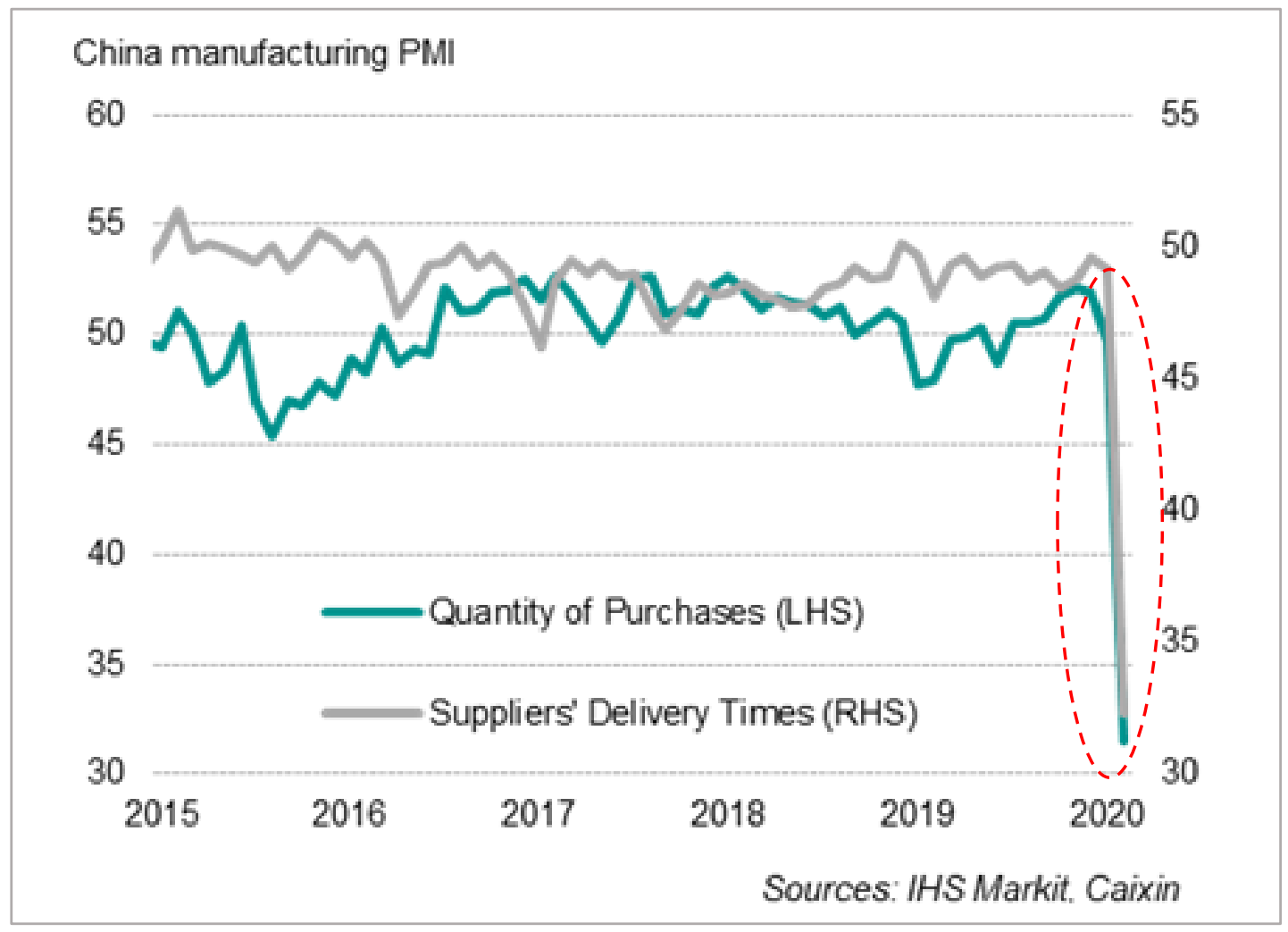

Gambar 3. Correlation Between LHS and $R H S^{8}$

Dengan adanya perpanjangan waktu pengiriman raw material sebagai dampak adanya Coronavirus COVID-19, menyebabkan terganggunya supply chain. Akibatnya, aktifitas pembelian juga menurun tajam.

\subsubsection{Penurunan Permintaan (Demand) BDI Dry Bulk Cargo}

Indikator yang tergambar dari the Baltic Dry Index (BDI) juga menyiratkan kelesuan yang sama. BDI menjelaskan keseimbangan pasar antara permintaan dan pasokan komoditas curah. Indikator ini bisa digunakan untuk menjelaskan tingkat perekonomian global karena berperan sebagai proksi volume perdagangan batubara, nikel, bauksit dan logam lain. Komoditaskomoditas tersebut umumnya dikirim dengan dry-bulk cargo (jenis capesize, panamax dan supramax).

\footnotetext{
${ }^{8}$ HIS Markit, Caixin, China Customs
} 


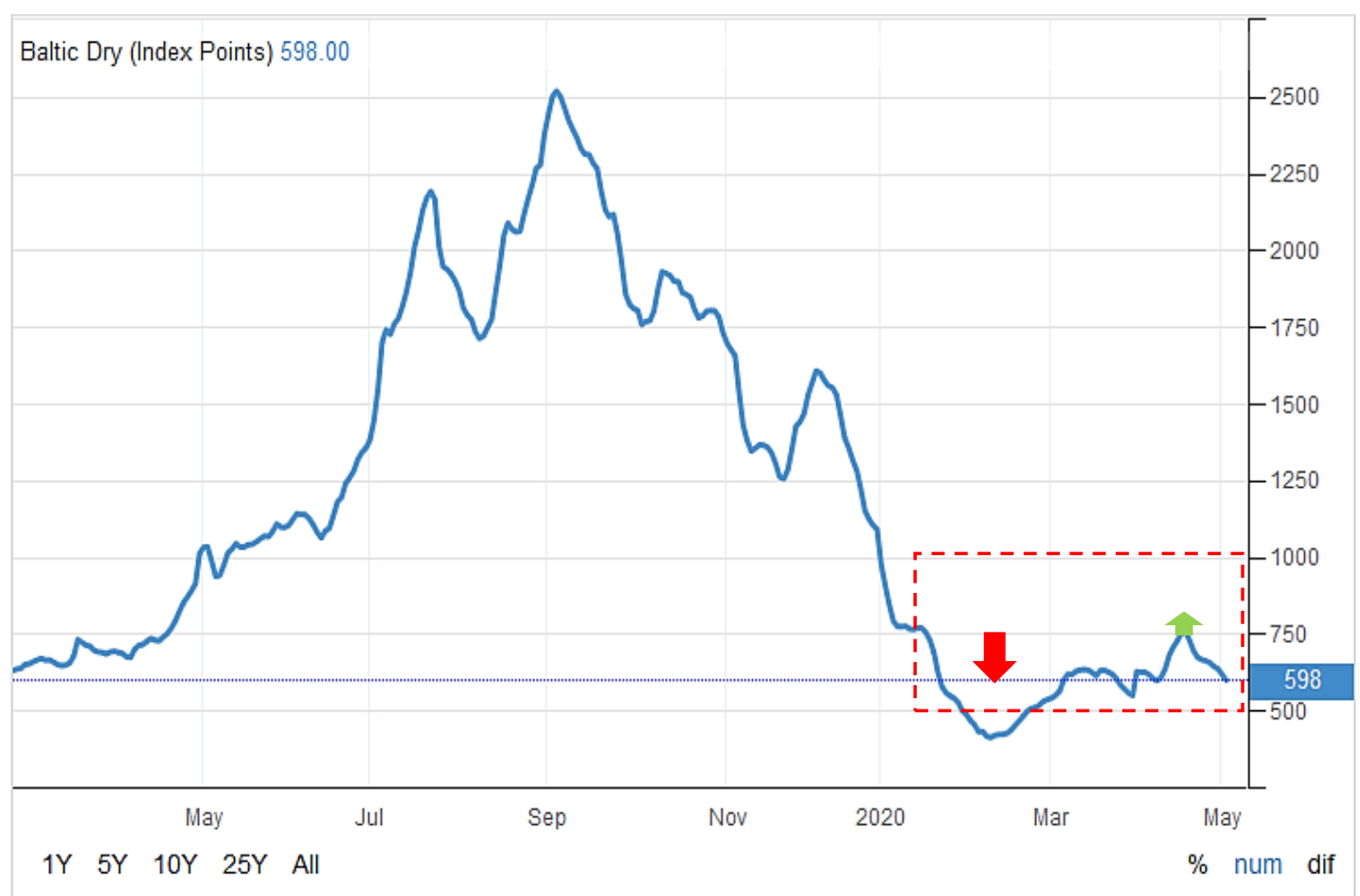

Gambar 4. Baltik Dry Index (BDI) ${ }^{9}$

Berdasarkan Trading Economy, diketahui bahwa terjadi penurunan sekitar 635 poin karena adanya pengaruh COVID-19. Akan tetapi, terjadi kenaikan kembali untuk pertama kalinya setelah tiga bulan terakhir yaitu pada bulan April terjadi kenaikan sebesar 700 poin. Hal ini disebabkan karena aktifitas di China yang berangsur-angsur membaik setelah pandemi Coronavirus COVID19. Seperti yang kita ketahui bahwa China merupakan penyumbang terbesar sekitar $40 \%$ dari total dry seaborne trade global. Hal ini diyakini memberikan dampak yang cukup signifikan terhadap kondisi perekonomian global secara menyeluruh.

\subsubsection{Penurunan Permintaan (Demand) BDI Dirty Tanker}

Semua indikator BDI yang dibuat berdasarkan jenis kapal yang beroperasi mengalami penurunan yang cukup drastis hingga di pekan ketiga Februari 2020. Temuan ini mengindikasikan sektor industri manufaktur global yang terus menurun. BDI untuk semua jenis kapal curah dan komoditas turun tajam sebesar 60\% dari 1090 di akhir bulan Desember 2019 menjadi hanya 465 di minggu ketiga Februari 2020. Demikian pula BDI dirty tanker (minyak) dan clean tanker (Liquid

\footnotetext{
${ }^{9}$ Baltic Exchange Dry Index, 2020
} 
Natural Gas/LNG) keduanya mengalami penurunan sebesar 45\% dan 25\%. Perlambatan ekonomi global benar-benar terlihat dengan semakin sedikitnya kargo curah yang diperdagangkan karena sebagian besar didorong oleh kelesuan di sektor manufaktur dan konstruksi.

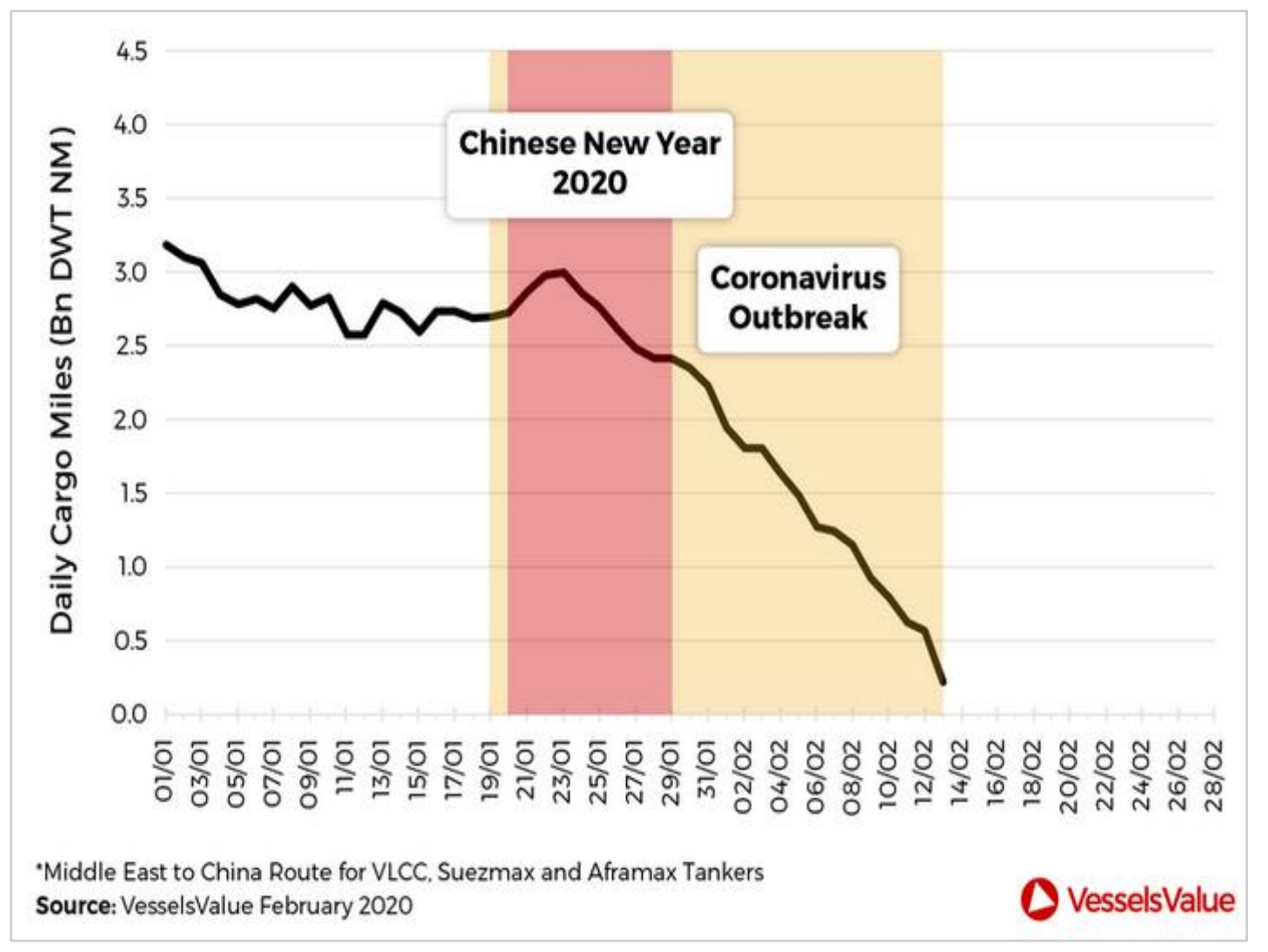

Gambar 5. 2020 Chinese Crude Tanker Demand ${ }^{10}$

Merebaknya virus corona telah membuktikan betapa tingkat ketergantungan industri pelayaran terhadap perekonomian China begitu tinggi. Jika aktivitas industri di China berhenti beroperasi, industri pelayaran akan stuck, tidak hanya sektor global supply chain, akan tetapi juga akan dapat memberikan dampak serius baik terhadap manufaktur, transportasi, pelayaran, maupun kegiatan kepelabuhanan. Berdasarkan data dari sustainable world port dilaporkan beberapa dampak yang terjadi di beberapa pelabuhan akibat adanya pandemi Coronavirus Covid-19 seperti ditunjukkan pada Gambar 6 dibawah ini.

${ }^{10}$ Vessels Value February, 2020 


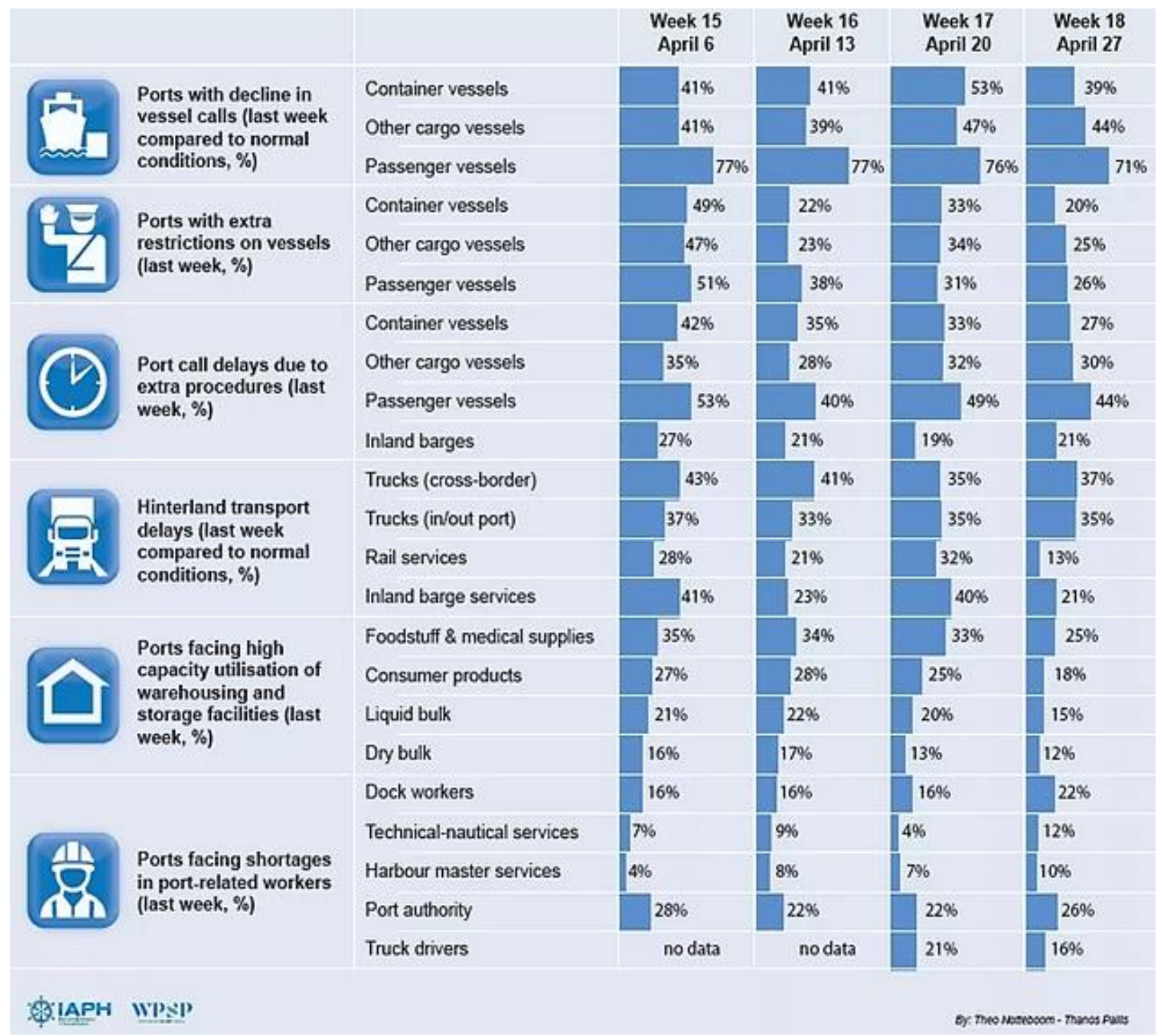

Gambar 6. World Port Sustainable Program Dashbord (WPSP) $)^{11}$

WPSP COVID19 Port Economic Impact Barometer

Data diatas menunjukkan barometer dari dampak ekonomi pelabuhan dari 76 pelabuhan di dunia akibat pamdemi Coronavirus Covid-19. Dilaporkan bahwa dari tujuh puluh enam pelabuhan yang disurvei di seluruh dunia dalam laporan Barometer Dampak Ekonomi Pelabuhan WPSP minggu ini, mayoritas melaporkan situasi yang relatif stabil dibandingkan dengan minggu-minggu sebelumnya, dengan sedikit peningkatan yang dicatat dalam beberapa bidang kontinuitas pelabuhan.

${ }^{11}$ Sustainable World Port, 2020 


\subsection{Dampak Coronavirus COVID-19 Terhadap Industri Kemaritiman di Indonesia}

\subsubsection{Sektor Pelayaran Nasional}

Sektor pelayan nasional tengah menghadapi tantangan yang berat seiring dengan mewabahnya pandemi Coronavirus Covid-19. Setidaknya terdapat 4 aspek yang terdampak di bisnis sektor pelayaran akibat mewabahnya Coronavirus, yaitu ${ }^{12}$ :

1. Penurunan Volume Kargo Ekspor Dan Impor

Penurunan volume kargo, baik pada ekspor impor yang terdampak seperti ke China yang menurun hingga 14-18 persen dan berdampak ke negara tujuan lain, seperti Singapura dan Korea Selatan. Begitu juga pada kargo domestik terutama pada kargo penunjang ekspor impor dan distribusi nasional yang turun 5-10 persen.

2. Proses Clearance Di Pelabuhan

Proses clearance di pelabuhan yang lebih lama karena adanya penyemprotan disinfektan kapal, pemeriksaaan kesehatan kru kapal dan pemeriksaan riwayat perjalanan kapal. Hal ini berdampak pada penambahan biaya operasional kapal.

3. Penurunan Kinerja Sebagai Dampak Physical Distancing Dan Work from Home (WFH) Kebijakan physical distancing dan work from home juga berdampak pada kinerja instansi di darat karena banyak yang membatasi jam kerja termasuk tenaga operasional di lingkungan Ditjen Hubla pada subdit-subdit terkait kepengurusan sertifikat kapal dan kesyahbandaran.

4. Permasalahan Docking Kapal

Pelayaran nasional juga mengalami kendala docking kapal. Hal ini disebabkan sejumlah galangan mengurangi jumlah pekerja di lapangan untuk meminimalisasi penyebaran Covid19. Akibatnya, pekerjaan perawatan kapal-kapal yang sedang docking terkendala entah sampai kapan, dan kapal lainnya harus antri lama untuk docking dalam dua bulan terakhir. Selain itu, spare part kapal yang impor dari China terkendala sehingga lebih lama dan lebih mahal. Kondisi yang sangat memukul sektor pelayaran nasional saat ini juga akan berdampak pada menurunnya kinerja industri terkait lainnya, seperti kinerja logistik, asuransi, galangan, industri spare part kapal hingga ke instansi pendidikan SDM pelaut.

\footnotetext{
12 Indonesia National Shipowners Association (INSA), 2020
} 


\subsubsection{Sektor Galangan Kapal}

Kondisi industri galangan kapal beberapa bulan terakhir memprihatinkan. Pasalnya, sebagian besar komponen kapal masih bergantung pada impor, sedangkan nilai tukar rupiah terhadap dolar Amerika Serikat terus menurun ${ }^{13}$. Produktivitas galangan pun menurun seiring arahan bekerja dari rumah (WFH) maupun physical distancing dari pemerintah. Selain produktivitas, hal tersebut juga membuat arus logistik terkoreksi yang berpotensi tertransmisikan pada pengurangan kebutuhan kapal.

\subsubsection{Sektor Kepelabuhanan}

Terdapat beberapa dampak yang berimbas pada sektor kepelabuhanan akibat pandemi Coronavirus Covid-19 di Indonesia, yaitu:

1. Penghentian Operasi Pelabuhan

PT Pelabuhan Indonesia II (IPC) untuk sementara menghentikan operasi 3 dari 5 terminal penumpang yang dikelolanya. Penutupan tersebut dilakukan karena kapal yang melayani penumpang di ketiga pelabuhan tersebut menghentikan sementara pelayanannya guna meredam meluasnya penyebaran virus Corona (Covid-19). Tiga terminal penumpang yang tutup sementara itu adalah terminal penumpang Pelabuhan Tanjung Pandan Belitung dan Pelabuhan Pangkal Balam Bangka, serta terminal penumpang Pelabuhan Boom Baru Palembang Sumatera Selatan. Sementara 2 terminal penumpang lainnya yang masih beroperasi yakni di Pelabuhan Tanjung Priok dan Pelabuhan Pontianak. Keputusan itu diambil oleh pihak pengelola kapal sebagai upaya mendukung program Pemerintah Daerah \& Provinsi dalam mencegah penyebaran Coronavirus Covid-19.

2. Keterlambatan Proyek Strategis Kepelabuhanan

Sejumlah proyek strategis di sektor kepelabuhanan yang saat ini sedang dikerjakan ataupun dijadwalkan untuk dilakukan oleh BUMN PT. Pelabuhan Indonesia II/IPC juga dikhawatirkan tidak selesai sesuai target ${ }^{14}$. Sebagaimana diketahui, saat ini, PT Pelindo II sedang menyelesaikan sejumlah proyek, termasuk pembangunan Terminal Kijing (Kalimantan

\footnotetext{
${ }^{13}$ Ikatan Perusahaan Industri Galangan Kapal dan Lepas Pantai (Iperindo), 2020

14 Indonesia Shipping Gazete (ISP), 2020
} 
Barat), penyelesaian proyek jalan tol Cilincing - Cibitung, serta tindak lanjut dari proyek New Priok, baik itu penyelesaian proyek area 57 meter NPCT1, maupun CT2 dan CT3. Dengan masifnya efek Coronavirus Covid-19 saat ini, ada kemungkinan penyelesaian proyek-proyek tersebut akan mundur.

Berdasarkan pembahasan diatas, terlihat sekali bahwa terjadi kelesuan tingkat nasional dibidang kemaritiman di Indonesia. Hal ini juga didukung oleh data empiris dari operasional Samudera Indonesia (SMDR). Data selama bulan Januari dan Februari menunjukkan tren penurunan volume perdagangan. Angka sementara menunjukkan bahwa pelabuhan SMDR di Tanjung Priok mencatat penurunan 10\% dari sisi volume kargo jika dihitung berdasarkan basis year-on-year (yoy) dibandingkan dengan bulan yang sama di tahun $2019^{15}$.

Dari sisi operasional kapal, volume muatan keluar (outbound cargo) 17\% lebih sedikit sementara volume muatan masuk (inbound cargo) 14\% lebih sedikit hingga pekan keempat Januari 2020 dibandingkan dengan periode yang sama di tahun 2019. Beberapa hal yang harus diantisipasi adalah:

1. Mempersiapkan tertundanya rantai pasokan manufaktur dalam beberapa bulan mendatang.

2. Sebagian kontrak perdagangan dari dan ke China dibatalkan atau ditangguhkan ke semester II-2020. Fenomena ini mempengaruhi permintaan dan penawaran komoditas mengingat besarnya porsi China sebagai produsen dan konsumen.

Berdasarkan penjelasan diatas, dapat ditarik kesimpulan bahwa pandemi Coronavirus Covid-19, telah memberikan dampak yang nyata, baik pada global shipping yang mempengaruhi kondisi supply chain secara umum, serta industri kemaritiman di Indonesia secara khususnya. Guna menjamin sustainability dari aktifitas di industri kemaritiman Indonesia yang sulit seperti saat ini, diperlukan adanya upaya pencegahan dan penanganan penyebaran Coronavirus Covid-19 di Indonesia sesuai dengan standar keselamatan international.

${ }^{15}$ Harya S.Dillon, Sekjen Masyarakat Transportasi Indonesia 2020 


\subsection{Rekomendasi World Health Organization (WHO)}

Organisasi Kesehatan Dunia atau World Health Organization (WHO) memberikan delapan rekomendasi penting kepada pemerintah Indonesia dalam rangka penanganan kasus penyebaran Coronavirus Covid-19. Rekomendasi penanganan Coronavirus Covid-19 tersebut disampaikan WHO kepada pemerintah Indonesia. Berdasarkan laporan hasil pertemuan tim WHO dengan tim pemerintah, WHO memberikan pertimbangan kepada Indonesia dalam rangka membuat kebijakan pencegahan.

Diskusi dengan WHO Jakarta mengenai pengendalian Coronavirus Covid- 19, Organisasi Kesehatan Dunia itu memberikan tiga pertimbangan kepada pemerintah Indonesia ${ }^{16}$.

1. Kesehatan penduduk merupakan prioritas utama bagi kebijakan pemerintah. Tetapi upaya yang dilakukan saat ini masih kurang maksimal.

2. Upaya mengurangi dampak ekonomi agar tidak diarahkan pada stimulus yang mendorong penyebaran infeksi. Seperti membuka keran turis asing, tetapi stimulus bagi perlindungan sosial seperti dampak bagi perusahaan, penyediaan bahan-bahan pokok dan lain-lain.

3. Dengan semakin meningkatkan surveilans dapat menangkap lebih banyak kasus suspek, tetapi dalam jangka menengah lebih dalam mitigasi dampak ekonomi dan kepercayaan dunia internasional.

Selain itu pemerintah Indonesia juga mendapatkan rekomendasi spesifik dari WHO:

1. Aktivasi emergensi nasional dan membentuk Tim Khusus yang memiliki kewenangan mengambil keputusan berbasis bukti-bukti.

2. Memperluas deteksi kasus secara intensif serta pelacakan kontak untuk mengetahui secara pasti di wilayah Indonesia mana saja yang terjadi penularan aktif;

3. Mendorong desentralisasi kapasitas laboratorium terutama pada laboratorium yang mempunyai kapasitas serta meningkatkan kapasitas lab yang ada. Dalam catatan Bappenas, saat ini hanya lab di Litbangkes yang melakukan tes. Sementara itu, Pemerintah Provinsi DKI

\footnotetext{
${ }^{16}$ Barly Haliem, 2020
} 
Jakarta yang sudah memiliki Lab Uji Covid-19 sampai saat ini belum diberikan kewenangan utk melakukan uji lab terhadap kasus infeksi virus corona Covid-19.

4. Mengumumkan kasus terkonfirmasi dan menyampaikan perincian pelacakan kontak segera kepada WHO agar dapat di analisa dan memberikan advise kepada pemerintah

5. Opsi containment antara lain: meliburkan sekolah; membatalkan pertemuan dalam jumlah besar; menghindari perjalanan ke tempat umum;

6. Mempromosikan dan menjaga jarak ketika bersosialisasi tidak boleh berjabat tangan, mencium atau memeluk dan langkah-langkah perlindungan dasar lain (mencuci tangan dan masker).

7. Menyarankan orang yang menunjukkan gejala pernapasan untuk tetap tinggal di rumah, mengisolasi diri, dan segera memeriksakan diri ke fasilitas pelayanan kesehatan.

8. Menyiapkan sarana dan prasarana yang diperlukan dalam jumlah besar di 132 RS rujukan. Sarana dan prasarana ini meliputi stok Alat Pelindung Diri, ventilator, respirator, dan bahan dan sarpras medis lainnya. Selain itu perlu kantong-kantong mayat dan tata cara pemakaman yang aman untuk setiap orang yang meninggal akibat infeksi saluran pernapasan.

\subsection{Rekomendasi International Maritime Organization (IMO)}

Organisasi Maritim Internasional (IMO) menerbitkan sejumlah rekomendasi, menyusul deklarasi "keadaan Darurat Global" dari Organisasi Kesehatan Dunia (WHO) atas berjangkitnya Virus Corona (2019-nCoV). WHO pada 30 Januari 2020 mendeklarasikan berjangkitnya Virus Corona (2019-nCoV) sebagai situasi darurat global atau Public Health Emergency of International Concern (PHEIC) ${ }^{17}$.

Situasi Darurat Global yang dimaksud WHO adalah peristiwa luar biasa yang berisiko mengancam kesehatan masyarakat negara lain melalui penularan penyakit lintas batas negara sehingga membutuhkan tanggapan internasional yang terkoordinasi. Namun WHO tidak merekomendasikan pembatasan perjalanan atau perdagangan antar negara, berdasarkan informasi terkini yang tersedia.

\footnotetext{
17 Jurnal Maritim, 2020
} 
IMO kemudian menerbitkan rekomendasi kepada seluruh Negara Anggota IMO, para pelaut, dan perusahaan pelayaran dalam dua surat edaran (cilcular letter). Rekomendasi IMO ini disusun dengan tetap mengacu pada rekomendasi yang dikembangkan oleh (WHO) dan Divisi Manajemen Kesehatan dan Keselamatan dan Kesehatan Kerja (DHMOSH) PBB. Rekomendasi IMO tersebut meliputi:

1. Surat Edaran No.4203 Novel Coronavirus (2019-nCoV) $)^{18}$

Berisi informasi dan panduan tentang tindakan pencegahan yang harus diambil untuk meminimalkan risiko bagi delegasi yang menghadiri pertemuan di IMO setelah merebaknya virus corona baru-baru ini (2019-nCoV).

2. Surat Edaran No.4204 Novel Coronavirus (2019-nCoV) $)^{19}$

Berisi informasi dan panduan tentang tindakan pencegahan yang harus diambil untuk meminimalkan risiko terhadap pelaut, penumpang, dan orang lain di kapal.

IMO juga merekomendasi untuk mengikuti saran-saran tambahan lainnya, antara lain:

- International Maritime Health Association (IMHA) advice for shipping companies

- US Cost Guard (USCG) Novel Coronavirus Precautions

Rekomendasi oleh IMO terhadap Member States, seafarers and shipping secara detail dijelaskan sebagai berikut:

Tabel 1. Surat Edaran International Maritime Organization (IMO)

\begin{tabular}{|c|c|c|l|}
\hline No & IMO's Circular Letter & Released Date & \multicolumn{1}{|c|}{ Advices } \\
\hline 1. & Circular Letter No.4203. Add 1 & $\begin{array}{c}12 \text { February } \\
2020\end{array}$ & $\begin{array}{l}\text { Information and guidance on the } \\
\text { precautions to be taken to minimize risks } \\
\text { to delegates }\end{array}$ \\
\hline 2. & Circular Letter No.4204/Add.1 & $\begin{array}{c}19 \text { February } \\
2020\end{array}$ & $\begin{array}{l}\text { Implementation and enforcement of } \\
\text { relevant IMO instruments }\end{array}$ \\
\hline 3. & Circular Letter No.4204/Add.2 & $\begin{array}{c}21 \text { February } \\
2020\end{array}$ & $\begin{array}{l}\text { Joint Statement IMO-WHO on the } \\
\text { Response to the COVID-19 Outbreak }\end{array}$ \\
\hline
\end{tabular}

18 IMO Circular Letter No.4203, 2020

19 IMO Circular Letter No.4204, 2020

${ }^{20}$ IMO Circular Letter No.4203. Add 1, 2020

${ }^{21}$ IMO Circular Letter No.4204/Add.1, 2020

22 IMO Circular Letter No.4204/Add.2, 2020 


\begin{tabular}{|c|c|c|c|}
\hline 4. & Circular Letter No.4204/Add.3 & 2 March 2020 & $\begin{array}{l}\text { Operational considerations for managing } \\
\text { COVID-19 cases/outbreak on board ships }{ }^{23}\end{array}$ \\
\hline 5. & Circular Letter No.4204/Add.4 & 5 March 2020 & $\begin{array}{l}\text { Guidance for ship operators for the } \\
\text { protection of the health of seafarers }{ }^{24}\end{array}$ \\
\hline 6. & $\begin{array}{c}\text { Circular Letter No.4204/Add.5/ } \\
\text { Rev }\end{array}$ & 2 April 2020 & $\begin{array}{l}\text { Guidance relating to the certification of } \\
\text { seafarers and fishing vessel personnel }\end{array}$ \\
\hline 7. & Circular Letter No.4204/Add.6 & $\begin{array}{l}27 \text { March } \\
2020\end{array}$ & $\begin{array}{l}\text { Preliminary list of recommendations for } \\
\text { Governments and relevant national } \\
\text { authorities on the facilitation of maritime } \\
\text { trade during the COVID- } 19 \text { pandemic }{ }^{26}\end{array}$ \\
\hline 8. & Circular Letter No.4204/Add.7 & 3 April 2020 & $\begin{array}{l}\text { Guidance concerning unforeseen delays in } \\
\text { the delivery of ships }{ }^{27}\end{array}$ \\
\hline 9. & Circular Letter No.4204/Add.8 & 14 April 2020 & $\begin{array}{l}\text { Video meeting with port State control } \\
\text { (PSC) regimes }{ }^{28}\end{array}$ \\
\hline 10. & Circular Letter No.4204/Add.9 & 16 April 2020 & $\begin{array}{l}\text { Joint Statement IMO-WCO on the integrity } \\
\text { of the global supply chain during the } \\
\text { COVID-19 pandemic }{ }^{29}\end{array}$ \\
\hline 11. & Circular Letter No.4204/Add.10 & 22 April 2020 & $\begin{array}{l}\text { Joint Statement IMO-WHO-ILO on medical } \\
\text { certificates of seafarers, ship sanitation } \\
\text { certificates and medical care of seafarers } \\
\text { in the context of the COVID-19 pandemic }{ }^{30}\end{array}$ \\
\hline 12. & Circular Letter No.4204/Add.11 & 24 April 2020 & $\begin{array}{l}\text { Coronavirus (COVID 19) - EC Guidelines on } \\
\text { protection of health, repatriation and } \\
\text { travel arrangements for seafarers, } \\
\text { passengers and other persons on board } \\
\text { ships }^{31}\end{array}$ \\
\hline 13. & Circular Letter No.4204/Add.12 & 27 April 2020 & $\begin{array}{l}\text { Coronavirus (COVID 19) - Declaration by } \\
\text { Port Authorities Roundtable (PAR) } \\
\text { members in view of the global COVID-19 } \\
\text { situation }{ }^{32}\end{array}$ \\
\hline
\end{tabular}

${ }^{23}$ IMO Circular Letter No.4204/Add.3, 2020

${ }^{24}$ IMO Circular Letter No.4204/Add.4, 2020

${ }^{25} \mathrm{IMO}$ Circular Letter No.4204/Add.5/ Rev, 2020

${ }^{26}$ IMO Circular Letter No.4204/Add.6, 2020

${ }_{27}$ IMO Circular Letter No.4204/Add.7, 2020

${ }^{28}$ IMO Circular Letter No.4204/Add.8, 2020

${ }^{29}$ IMO Circular Letter No.4204/Add.9, 2020

${ }^{30}$ IMO Circular Letter No.4204/Add.10, 2020

31 IMO Circular Letter No.4204/Add.11, 2020

32 IMO Circular Letter No.4204/Add.12, 2020 
Negara Anggota IMO disarankan untuk mendesak seluruh pemangku kepentingan di negaranya (perusahaan, manajer, agen kru, dll.) untuk terlibat menyebarluaskan edaran IMO di atas. IMO ingin memastikan bahwa seluruh masyarakat maritim dunia memperoleh informasi yang akurat dan relevan tentang wabah Coronavirus Covid-19 dan langkah-langkah untuk mengurangi risiko terpapar virus tersebut, terutama yang berada di kapal-kapal yang berlayar di antara pelabuhan-pelabuhan di negara-negara yang terkena Coronavirus.

Sikap dari Pemerintah Indonesia adalah melakukan tindakan untuk membatasi risiko penyebaran Coronavirus, tanpa pembatasan terhadap lalu lintas barang internasional dimana sejalan dengan rekomendasi dari IMO dan WHO. Konsekuensinya adalah, Kementerian Perhubungan cq. Direktorat Jenderal Perhubungan Laut (DJPL) menyatakan akan mengawasi secara ketat pelaksanaan rekomendasi IMO dan WHO terkait peningkatan pengawasan dan pencegahan terhadap masuknya Coronavirus Covid-19 ke tanah air terutama penyebaran yang melalui jalur-jalur pelayaran international dan transportasi kapal. Upaya lain yang juga dilakukan adalah dengan melaksanakan anjuran sosial distancing dan work from home (WFH).

\section{Kesimpulan}

Merebaknya Coronavirus Covid-19 telah membuktikan betapa tingkat ketergantungan seaborn trade dan global shipping terhadap perekonomian China begitu tinggi. Hal ini disebabkan karena China menjadi role major player yang memiliki konstribusi lebih dari $40 \%$ dry seaborn trade global. Jika aktivitas industri di China berhenti beroperasi, industri pelayaran menjadi stuck, global supply chain akan terimbas, serta akan memberikan dampak serius baik terhadap sektor manufaktur, transportasi, maupun kegiatan kepelabuhanan. Dampak nyata dari pandemi Coronavirus Covid-19 di terhadap industri kemaritiman di Indonesia terjadi pada 3 sektor utama yaitu, sektor pelayaran nasional, sektor galangan kapal, dan sektor kepelabuhanan. Sedangkan untuk menjaga sustainability aktifitas kemaritiman dan mencegah penyebaranan Coronavirus Covid-19, pemerintah Indonesia melakukan pengawasan dengan ketat dalam melaksanakan rekomendasi yang telah diberikan tersebut. Upaya lain yang juga dilakukan adalah dengan melaksanakan anjuran sosial distancing dan work from home (WFH) terhadap pihak-pihak terkait di dunia kemaritiman Indonesia. 


\section{Referensi}

Baltic and International Maritime Council (BIMCO), 2020, Dampak Coronavirus Semakin Serius, Penurunan Volume China Tembus 1,7 Juta TEUS, https://indoshippinggazette.com/2020/dampak-coronavirus-semakin-serius-penurunanvolume-china-tembus-17-juta-teus/

Sand (BIMCO), 2020, Virus Corona: Kehilangan Pendapatan Pelayaran Sudah Tembus \$1,5 miliar atau Rp 21 Triliun, https://indoshippinggazette.com/2020/virus-corona-kehilanganpendapatan-pelayaran-sudah-tembus-15-miliar-atau-rp-21-triliun/

Reported Cases and Deaths by Country, Territory, or Conveyance https://www.worldometers.info/coronavirus/, 2020.

Studi Kepustakaan, 2020

http://repository.usu.ac.id/bitstream/handle/123456789/33144/Chapter\%20ll.pdf;jsession $\underline{\text { id=FEBAF8D9303F5196385AC2E24607215B?sequence=3 }}$

Dana Riska Buana, 2020, Analisis Perilaku Masyarakat Indonesia dalam Menghadapi Pandemi Virus Corona (Covid-19) dan Kiat Menjaga Kesejahteraan Jiwa, https://www.researchgate.net/publication/340103659 Analisis Perilaku_Masyarakat Ind onesia dalam Menghadapi Pandemi Virus Corona Covid-

\section{9 dan Kiat Menjaga Kesejahteraan Jiwa/citations}

Nana Sudjana dan Ibrahim, 1989, Penelitian dan Penelitian Pendidikan, Bandung: Sinar Baru, hlm. 64

HIS Markit, Caixin, China Customs, 2020, Caixin China manufacturing PMI falls to survey low on coronavirus countermeasures, https://ihsmarkit.com/research-analysis/caixin-chinamanufacturing-pmi-falls-to-survey-low-on-coronavirus-countermeasures.html

HIS Markit, Caixin, China Customs, 2020, Coronavirus-related shortages of raw materials disrupted supply chains, constributing to delivery times lenghtening at a survey-record rate, https://ihsmarkit.com/research-analysis/caixin-china-manufacturing-pmi-falls-to-surveylow-on-coronavirus-countermeasures.html

Baltic Exchange Dry Index, Trading Economy https://tradingeconomics.com/commodity/baltic , 2020 
Vessels Value February, 2020, Coronavirus causes China crude tanker demand to plummet:

VesselsValue,https://www.oilandgasmiddleeast.com/products-services/36181-coronaviruscauses-china-crude-tanker-demand-to-plummet-vesselsvalue

Sustainable World Port, 2020, https://sustainableworldports.org/wpsp-covid19-port-economicimpact-barometer-for-week-18-reports-stabilization-or-slight-improvements/

Indonesia National Shipowners Association (INSA), 2020, Pelayaran Mulai Terpukul Akibat

Covid-19, https://insa.or.id/category/insa-insight/

Ikatan Perusahaan Industri Galangan Kapal dan Lepas Pantai (Iperindo), 2020, Virus Corona Buat Galangan Kapal Jadi Berkarat, https://ekonomi.bisnis.com/read/20200326/257/1218536/virus-corona-buat-galangankapal-jadi-berkarat

Indonesia Shipping Gazete (ISP), 2020, Dampak Covid-19 terhadap Implementasi Proyek

Strategis Kepelabuhanan,https://indoshippinggazette.com/2020/dampak-covid-19-

terhadap-implementasi-proyek-strategis-kepelabuhanan/

Harya S.Dillon, Sekjen Masyarakat Transportasi Indonesia, 2020, Dampak Korona ke Logistik \&

Transportasi, https://analisis.kontan.co.id/news/dampak-korona-ke-logistik-transportasi

Barly Haliem, 2020, WHO rekomendasikan Indonesia lakukan delapan tindakan hadapi virus

corona Covid-19, https://nasional.kontan.co.id/news/who-rekomendasikan-indonesia-

lakukan-delapan-tindakan-menghadapi-virus-corona

Jurnal Maritim, 2020, Rekomendasi IMO Menghadapi Darurat Global Virus Corona,

https://jurnalmaritim.com/ini-rekomendasi-imo-tentang-keadaan-darurat-global-virus-

corona/

IMO Circular Letter No.4203, 2020,

http://www.imo.org/en/MediaCentre/HotTopics/Documents/4203\%20add\%201.pdf

IMO Circular Letter No.4204, 2020,

http://www.imo.org/en/MediaCentre/HotTopics/PublishingImages/Circular\%20Letter\%20

No.4204\%20\%20Novel\%20Coronavirus\%202019-Ncov\%20Secretariat.pdf

IMO Circular Letter No.4203. Add 1, 2020,

http://www.imo.org/en/MediaCentre/HotTopics/Documents/4203\%20add\%201.pdf

Jurusan Teknik Sistem Perkapalan, Fakultas Teknologi Kelautan, Universitas Darma Persada, DKI Jakarta, 2020 
IMO Circular Letter No.4204/Add.1, 2020

http://www.imo.org/en/MediaCentre/HotTopics/Documents/CL.4204-

Add.1\%20English.pdf

IMO Circular Letter No.4204/Add.2, 2020,

http://www.imo.org/en/MediaCentre/HotTopics/Documents/Circular\%20Letter\%20No.42

04-Add.2\%20-\%20Joint\%20Statement\%20Imo-

Who\%200n\%20The\%20Response\%20To\%20The\%20Covid-

19\%200utbreak\%20(Secretariat).pdf

IMO Circular Letter No.4204/Add.3, 2020

http://www.imo.org/en/MediaCentre/HotTopics/Documents/Circular\%20Letter\%20No.42

04-Add.3.pdf

IMO Circular Letter No.4204/Add.4, 2020

http://www.imo.org/en/MediaCentre/HotTopics/Documents/Circular\%20Letter\%20No.42

04-Add.4.pdf

IMO Circular Letter No.4204/Add.5/ Rev, 2020

http://www.imo.org/en/MediaCentre/HotTopics/Documents/Circular\%20Letter\%20No.42

04\%20Add.5\%20Rev.1.pdf

IMO Circular Letter No.4204/Add.6, 2020

http://www.imo.org/en/MediaCentre/HotTopics/Documents/Circular\%2OLetter\%20No.42

04Add.6\%20\%20Coronavirus\%20Covid-

19\%20Preliminary\%20List\%200f\%20Recommendations.pdf

IMO Circular Letter No.4204/Add.7, 2020

http://www.imo.org/en/MediaCentre/HotTopics/Documents/Circular\%20Letter\%20No.42

04-Add.7\%20-\%20Coronavirus.pdf

IMO Circular Letter No.4204/Add.8, 2020

http://www.imo.org/en/MediaCentre/HotTopics/Documents/Circular\%20Letter\%20No.42

04-Add.8\%20-

\%20Coronavirus\%20Video\%20Meeting\%20With\%20Port\%20State\%20Control.pdf

Jurusan Teknik Sistem Perkapalan, Fakultas Teknologi Kelautan, Universitas Darma Persada, DKI Jakarta, 2020 
IMO Circular Letter No.4204/Add.9, 2020

http://www.imo.org/en/MediaCentre/HotTopics/Documents/Circular\%20Letter\%20No.42 04-Add.9\%20-

\%20Joint\%20Statement\%20ImoWco\%200n\%20The\%20Integrity\%200f\%20The\%20Global\% 20Supply\%20Chain.pdf

IMO Circular Letter No.4204/Add.10, 2020

http://www.imo.org/en/MediaCentre/HotTopics/Documents/COVID\%20CL\%204204\%20ad ds/Circular\%20Letter\%20No.4204-Add.10\%20-\%20Joint\%20Statement\%20Imo-WhoIlo\%200n\%20Medical\%20Certificates.pdf

IMO Circular Letter No.4204/Add.11, 2020

http://www.imo.org/en/MediaCentre/HotTopics/Documents/COVID\%20CL\%204204\%20ad ds/Circular\%20Letter\%20No.4204-Add.11\%20-\%20Coronavirus\%20Covid\%2019\%20\%20Ec\%20Guidelines\%200n\%20Protection\%200f\%20Health\%20Repatriation.pdf

IMO Circular Letter No.4204/Add.12, 2020

http://www.imo.org/en/MediaCentre/HotTopics/Documents/COVID\%20CL\%204204\%20ad ds/Circular\%20Letter\%20No.4204-Add.12\%20-\%20Coronavirus\%20(Covid\%2019)\%20\%20Declaration\%20By\%20Port\%20Authorities\%20Roundtable.pdf 